\title{
THE EFFICACY OF THE CASE STUDY METHOD IN TEACHING FOREIGN LANGUAGES TO STUDENTS AND LEARNERS IN VARIOUS LANGUAGE COURSES AT HIGHER EDUCATION INSTITUTIONS
}

\author{
Elena Dorofeeva ${ }^{1}$, Ramziya Gubaydullina ${ }^{2}$ \\ ${ }^{1}$ Assoc. Prof. Dr., Kazan Federal University, Russian Federation, elena.dor@mail.ru \\ ${ }^{2}$ Senior Teacher, Kazan Federal University, Russian Federation, ramzia.gubaidi@gmail.com
}

\begin{abstract}
Nowadays, learning foreign languages is a relevant issue for both students and professionals in different fields of industry. The purpose of this article is to consider the Case Study method, its advantages and efficacy and cogency in comparison with other methods of foreign language teaching and to present the analysis of the results of the study of the application of this method in foreign language classes with students and practitioners (students of business programs and business courses), presenting their perception and attitude to the use of this method in classes. "Case Study", a case study method, is the method of situational learning used to solve practical educational tasks in foreign language teaching. It is based on a problematic situation, either simulated or real, which needs to be analysed, assessed, discussed and solutions to be found. The authors surveyed foreign language students of Kazan Federal University, practitioners and learners of various foreign language programmes and courses for different purposes. The questions posed to the learners about the difficulty of performing the tasks, cognitive interest in this method and effectiveness of its application in foreign language classes were investigated and analyzed. The research on this issue showed both the effectiveness of this method and the necessity of its use in foreign language learning. At the same time, the analysis of the responses also led to the conclusion that an individual approach to work with different categories of learners is advisable.
\end{abstract}

Keywords: teaching, linguistics, foreign languages, Case Study method, students, professionals, learners, research, analysis

\section{INTRODUCTION}

The development of modern society in all spheres of life and the expansion of borders with foreign partners creates demand for highly qualified specialists with a high knowledge of foreign languages. They should be professionally competent, comprehensively developed, creative and socially active. These requirements cause the main task of higher education institution: to train competitive professionals. The globalization of production in all spheres in our society does not allow getting along with one language, in particular, Russian, while promoting business. There is an emerging need for proficiency in at least one of the European languages which is a prerequisite for a successful specialist.

\subsection{Relevance of the Study}

Learning a language does not only mean solving language problems. Trainees can learn different language units by reflecting on extraneous topics, which allows them to memorize language units or phrases, 
grammatical structures, etc., doing so as it happens. The relevance of our study stems from the fact that a foreign language teacher has to solve linguistic tasks as well as to prepare students for their future professional activities. In our opinion, the most effective method of foreign language teaching for this task is the Case Study method in groups where learners can differ in their age, profession and fields of activity. It is both effective and efficient because it is in the line with the time and is based on the society development strategy, future-oriented, updated with goals and content, educational technologies, organizational forms and management mechanisms.

The Case Study method is based on a real, topical problem situation from the business world that needs to be solved through the discussions. This method should be used to develop communicative, linguistic, subject, methodological and sociolinguistic competences of future specialists.

The aim of the Case Study method is to analyse a certain situation proposed by the teacher and additional information materials (using the potential of a group of students or foreign language learners), develop an optimal solution and present it to the audience. At the end of the presentation of the solutions found, the best option should be chosen. The process of analysing the situation and finding a solution is of great value for students and learners [3].

According to K. Nodari, this method allows students to analyse different real-life situations, focusing primarily on the application of practical skills, and thus it is not a simple reproduction of previously obtained theoretical knowledge [4, p.176].

The work done by students and learners in groups on a problem situation can be divided into the following stages:

1. Analysing of the presented material, formulation of the problem;

2. Searching for and collecting additional information (if necessary);

3. Discussing of different variants of solving the problem;

4. Choosing the best solution based on comparison of all the proposed solutions;

5. Presenting and defending of the solution [3].

The main point when working on a problem situation is that it (a problem situation) should be relevant and taken from the life of a real existing company. And the task of the foreign language teacher is to select a situation from the business world and methodical processing of this case, i.e. its adaptation to the needs of foreign language teaching. The teacher should carefully prepare the material, select the appropriate vocabulary on a certain topic, grammar material, language clichés necessary for discussing solutions to problematic situations, preparing presentations, etc.

\subsection{The hypothesis of the Study}

Despite the difficulties of applying this method in teaching a foreign language to students and learners which primarily require a high level of speaking (presence of $\mathrm{B} 1$ - $\mathrm{C} 1$ level), availability of certain knowledge of special subjects to be able to solve cases, the Case Study method has many advantages in teaching a foreign language for professional and business communication. The method allows:

1) To improve the language skills of the students/learners;

2) To take into account personal and professional needs of students/learners, their individual psychological features;

3) To monitor knowledge;

4) To apply all forms of classroom work: frontal, individual, paired, group;

5) To develop all types of speech activity: reading (observation, selective, detailed), speaking (monological and dialogical), writing (planning, essay writing, etc.), listening and translation;

6) To implement inter-subject links;

7) To stimulate creative activity of students and learners;

8) To form various competences needed by students in their future professional life

9) To form and develop students' ability to work with different types of reference literature, dictionaries, to schematically present the information obtained [3]. 


\section{METHODS}

While investigating the issue of the "Case Study" method we used the following research techniques: studying and analysis of the theoretical and practical work in methodology; analysis of textbooks and manuals in the English language used for teaching English language to students/learners; the subject-logical analysis of texts of economic and business content in English; studying and generalization of experience of teaching on teaching English language for mixed-aged and various professional groups; oral interviews with the students; teaching experiment; conducting a survey and mathematical processing of the data obtained [6].

In the course of the experiment there was carried out a survey. The survey had the following objectives:

1) To analyse the work when the case study itself is carried out by the groups;

2) To determine the trainees' interest in the above-mentioned method;

3) To identify the difficulties in using it;

4) To identify the necessity of using the method in further teaching.

We conducted a survey. 41 respondents were 2nd year students of the Institute of Management, Economics and Finance of Kazan Federal University, aged 17-18 (direction: management, human resources, service, trade), 38 people were business program learners (employed in oil refining and engineering industries) aged 28-40, as well as 11 English language learners for various purposes (sportsmen, housewives, salesmen, drivers, graduate students, lawyers) aged 23-45.

\section{RESULTS}

Before using the" Case Study" method in our foreign language classes and conducting a survey of students and learners on the effectiveness of this method, we carefully studied the emerging of this method, the classification of cases, the algorithm, rules and requirements for tasks using the "Case Study" method, familiarized with the objectives that it pursues in foreign language teaching, analyzed ways of acquiring knowledge and skills through this method, based on the study of special literature convinced of the effectiveness of application We convinced that the use of this method in the teaching of foreign languages increases students' cognitive interest and motivation to learn languages.

We used the situation from the textbook "Market Leader" (Intermediate level, lesson 8) as a case study which was as follows: a travel agency, quite successful, having analysed the activities of the company, came to the conclusion that a reorganisation in three directions was necessary:

- Firstly, the management/management structure had to be reviewed.

- Secondly, the location of the offices (staff, management, break room) had to be changed.

- Thirdly, the working conditions had to be reviewed [1].

According to the assignment, the discussion should take place in pairs, then in groups. In working with the students (group 1) we observed the reasoning behind each of the proposed items. The students voiced the advantages and disadvantages of each option presented. The business programme learners, professionals and English language learners (group 2) chose one of the most effective options - redesigning the company's internal space. They calculated how much more economically beneficial it would be to correctly allocate all departments and employees, improve the psychological climate and logistics, and increase the useful area involved in the production process. Other solutions to this problem were also suggested, such as changing not only the management structure, but also changing the structure of the agency's departments themselves and technological upgrades. Group 3 had some difficulty with the solution, but it was found that also indicated that the task had been completed. Their reasoning, summing up, in our opinion, was very similar to the work of the group of students.

Based on our observations of the students' performance in this work, we have come to the conclusion that the experience of production activities allows us to significantly increase planning opportunities, engage more flexible solutions, and increase initiative. At the same time, the students were using ready-made templates, gaining experience and preparing to apply the acquired knowledge in their future professional activities. The course learners also used ready-made templates like the students, but unlike the first two groups, they were not more interested in the problem itself, but in communication in English.

As it has already been mentioned, practicing the "Case Study" method, in our opinion, is effective as it allows 
us to solve many problems. However, it should be noted that the main task is the language immersion. This method seems to us to be an integrated professional approach that develops reading, speaking and listening skills. It creates a comfortable learning environment where a student feels his/her success, his/her intellectual coherence which makes the process of productive learning knowledge and skills, and he/she becomes a full participant in the perception process, his/her experience being the main source of academic knowledge. In this method, the student is given the opportunity to test theory in practice, his or her ability to think creatively. On the other hand, the practical situation additionally arouses interest in the learning process, as it becomes clear what theoretical knowledge is lacking to solve the problem. We believe regular using of the case method in foreign language classes allows us to practice vocabulary, colloquial clichés, grammatical structures, i.e. to develop speaking skills in a foreign language [2].

You can see the students and learners' answers to the poll on the "Case Study" method

\begin{tabular}{|c|c|c|c|}
\hline & $\begin{array}{l}\text { Students } \\
(\%)\end{array}$ & $\begin{array}{l}\text { Professionals } \\
\text { (\%) }\end{array}$ & Learners (\%) \\
\hline $\begin{array}{l}\text { 1. Do you like the method "Case Study" while learning the } \\
\text { English language? }\end{array}$ & 90 & 95 & 85 \\
\hline \multicolumn{4}{|l|}{ 2. What difficulties did you face when solving the case: } \\
\hline a) a lack of common vocabulary & 44 & 72 & 70 \\
\hline b) a lack of special (professional) terminology & 60 & 34 & 90 \\
\hline c) a lack of grammar structures & 51 & 83 & 88 \\
\hline d) a lack of understanding of the problem to be solved & 10 & 2 & 18 \\
\hline $\begin{array}{l}\text { 3. Do you think the method is effective to learn the English } \\
\text { language? }\end{array}$ & 95 & 96 & 85 \\
\hline
\end{tabular}

To the question " Do you like the method "Case Study" while learning the English language?", all categories of learners responded positively, also agreeing on the prospect of using this method. When asked about the difficulties they experienced when using the method, they all stated that they had lacked the vocabulary, grammatical structures and colloquial clichés. It is noteworthy that while for students and trainees of English language courses special terminology is a problem, general vocabulary is a problem for specialists.

It is worth noting that while learning the English language students and learners applied their foreign language knowledge to hypothetical situations, business education trainees analysed practical situations in a foreign language. They were less fixated on grammatical mistakes, more communicative and more interested in analysing the work experiences of their classmates.

\section{CONCLUSIONS}

All the findings of the present research are as follows:

1. Students, professionals, learners of English language courses are satisfied with such type of learning as the "Case Study" method because it helped them to improve their language skills, made the process of learning a foreign language more interesting, exciting and turned it into a collaborative work with other learners and the teacher.

2. The efficacy of using the "Case Study" method in teaching English to students, professionals and learners 
was confirmed.

3. The "Case Study" method can be applied at all levels of language proficiency taking into account the gradation of case studies in terms of complexity.

4. Before entering the method in classes, it is necessary to thoroughly prepare, practicing vocabulary on a certain topic, grammatical structures, language clichés necessary for discussions, making and presenting their solutions.

5. When using this method in groups without any knowledge in business, it is necessary to choose situations that are understandable to all participants.

6. With the most prepared groups an improvisation can be used, where the case method is derived from any high-profile events of the moment.

Thus, practicing the "Case Study" method in the classes in the teaching of foreign languages is effective, as it allows not only to expand knowledge, develop all kinds of speech activity, increase cognitive interest and motivation to learn foreign languages, but also to form the skills necessary in the future professional activity of students and learners.

\section{REFERENCE LIST}

1. David Cotton, David Falvey, Simon Kent Market Leader, Intermediate, Business English. Course book, Longman, 2011. S. 68-69.

2. Dorofeeva E., Gubaidullina R. Combination of various forms of teaching activities in foreign languages classes at Higher Education Institutions // Proceedings of 5th International Multidisciplinary Scientific Conference on SOCIAL Sciences and Arts, SGEM 2018. Bulgaria, 24 August-2 September, 2018. Pages 109 - 114.

3. Matyushenko V.V. Case Study Method in Teaching a Foreign Language to Non-linguistic Students // Bulletin of the Moscow State Regional University. Series: Pedagogy. 2010. № 4. pp. 128-132.

4. Nodari Claudio. Perspektiven einer neuen Lernkultur. Pädagogische Lehrziele im Fremdsprachenunterricht als Problem der Lehrwerkgestaltung. Verlag Sauerländer- Aarau, Frankfurt am Mein, Salzburg, 1995, 262 P. 